\title{
COMPARATIVE CHROMOSOME AND MOLECULAR STUDIES OF SOME SPECIES OF GENUS ARUM FROM EASTERN SLAVONIA AND BARANYA REGION IN CROATIA
}

\author{
ANita Lendel ${ }^{1}$, MARIJA Bedalov ${ }^{2}$, MiRJANA SABO $^{3}$, \\ TOMISLAV BAČIĆ ${ }^{4}$, LJILJANA KRISTIN ${ }^{4}$, TIHANA MARČEK ${ }^{3}$ \\ ${ }^{1}$ Institut für Systematische Botanik \\ Zollikerstrasse 107, CH - 8008 Zürich, Switzerland \\ 2 Universite de Neuchâtel, Laboratorie de Botanique Evolutive \\ Rue Emile-Argand 11, 2007 Neuchâtel, Switzerland \\ ${ }^{3}$ Faculty of Food Technology, J.J. Strossmayer University \\ Kuhačeva 13, 31000 Osijek, Croatia \\ e-mail: mirjana.sabo@ptfos.hr \\ ${ }^{4}$ Faculty of Philosophy, J.J. Strossmayer University \\ L. Jägera 9, 31000 Osijek, Croatia
}

(Received: July 11, 2005. Accepted: June 19, 2006)

\begin{abstract}
Karyological and molecular studies were done in this paper on three species of genus Arum; Arum italicum Mill. and Arum maculatum L., with two varieties, and Arum alpinum Schott \& Kotschy, also with two varieties. The main goal of this paper was to establish whether they were regularly determined exclusively on the principle of morphological parameters. Karyological studies showed that the number of chromosomes for Arum italicum Mill. amounted to $2 \mathrm{n}=84$, for Arum maculatum L. $2 \mathrm{n}=56$ and for Arum alpinum Schott \& Kotschy $2 \mathrm{n}=28$. This confirmed that these species are not only clean and separated, but also support the regularity of the morphological determination. Molecular studies, e.g. RAPD method showed that two genetically separated species groups correspond to the three mentioned species. Arum italicum Mill. is the least homogenous species closely related and the variability between populations is high. Arum maculatum L. is more homogenous within the species, two varieties could be differentiated whereas they are closely genetically related and the variability between the populations is too high. Arum alpinum is strongly homogenous and within these species two varieties could also be differentiated. That means that they are closely related and the variability between the populations is very high. These observations mostly coincided with previous morphological investigations.
\end{abstract}

KEY WORDS: Arum species, chromosomes, molecular studies.

\section{INTRODUCTION}

This work is a continuation of our research presented in the previous paper (Lendel et al. 2004). As it has already been said, the three species, the two with two varieties, were determined in general as regular ones on the five localities exclusively on the basis of morphological parameters. The species are: Arum italicum Mill., Arum maculatum L. var. maculatum L., Arum maculatum L. var. immaculatum Reichb., Arum alpinum Schott \& Kotschy var. pannonicum Terpó and Arum alpinum Schott. \& Kotschy var. intermedium Terpó. The species Arum maculatum L. var. immaculatum Reichb. and Arum alpinum Schott. \& Kotschy, both with two varieties, are not mentioned in Flora Europaea
(1964-1980) or in Flora of Croatia (Domac 1994). The habitats are: Zablacee, Katunište and Normanci in Eastern Slavonia and Bilje and Branjin Vrh in Baranya. The regular identification of the species of genus Arum has presented a great problem from the beginning (Boys 1993). Studies of the species of genus Arum go back into the past (Reinchenbach 1830; Schott and Kotschy 1851; Schott 1860; Prime 1961; Terpó 1971, 1973, 1992; Bedalov 1975-1977, 1981, 1983; Bedalov and Fischer 1994; Bedalov et al. 1998), but the identifications of the separate species have not been sufficient until today. The purpose of this study is to establish, through investigations of chromosomes and molecular studies, whether the previous morphological studies were exactly true. 


\section{MATERIAL AND METHODS}

\section{Habitats, species and samples}

One of the leaves of each species of genus Arum was chosen for the studies in each of the following localities in Eastern Slavonia and Baranya region in Croatia. The localities in Eastern Slavonia were: Zablaće, Katunište and Normanci in which Arum italicum Mill., Arum maculatum L. var. maculatum L. and Arum maculatum L. var. immaculatum Reichb are growing. The localities in Baranya were Bilje and Branjin Vrh. In these habitats two Arum species were: Arum alpinum Schott \& Kotschy var. pannonicum Terpó and Arum alpinum Schott \& Kotschy var. intermedium Terpó.

\section{Karyological investigations}

The observations and counting of the number of chromosomes of the species of genus Arum were performed in mitotic cells placed in apical meristem of rootlets apex. The rootlets were fixed during October when its growth is rapid. The pre-treatment consisted of rootlets treatment by saturated water solution of $\alpha$-bromonaphtalen during 2.30 to 4.30 hours. After that followed the fixation in aceti alcohol (1:3) and dying with acetocarmine and ferrum acetate. After warming up, during two minutes, "squash" of cells was made. Chromosomes were counted by light microscope (Dialux $20 \mathrm{~EB}$, Leitz, Germany) at the immersion magnification of 1000x.

\section{Molecular measurements}

Molecular measurements involved the following treatments: DNA extraction, quantification of extracted DNA, random amplification of polymorphic DNA (RAPD), and gel electrophoresis.

\section{DNA extraction}

DNA was extracted from leaf tissue dried in silica gel of each investigated species of the genus Arum. The extraction was done by Quiagen Dneasy ${ }^{\mathrm{TM}}$ Plant Mini Kit (Quiagen, Basel) and performed with liquid nitrogen $\left(\mathrm{N}_{2}\right)$ that destroyed plant tissues and cells. The destroyed cells were then lysed by adding a lysis buffer (400 $\mu$ API, Quiagen) and incubated at $65^{\circ} \mathrm{C}$ during ten minutes. In such a sample Rnaze (4 $\mu$ l Rnase A, Quiagen) was added to destroy RNA. After polysaccharide and proteins precipitation at $40^{\circ} \mathrm{C}$ a centrifuge removed the other cell remains.

\section{Determination of extracted DNA concentration}

The concentration of extracted DNA was determined by the Lightwave UV/VIS Diode-Array Spectrophotometer (WPA Ldt, Cambridge). Aliquot of DNA stock solution was prepared to $\sim 30 \mu \mathrm{g} / \mu \mathrm{l}$ by a sample concentration or dilution and stored at $4^{\circ} \mathrm{C}$ for further use.

\section{Random amplification of polymerase DNA}

This method is a treatment with molecular marks. The method is based on different segments of DNA, which can be isolated from the plants, e.g. polymorphic enzymes, and then mutually compared. In the analysis of genome of the species of genus Arum the RAPD method, or AFLP, RFLP; SSR and SNP, was chosen. The principle of this method is a multiple randomly selected DNA sequence between two monomial DNA if they are at a certain distance. The result of this reaction is visualised as electrophoregram with either one or more visible bands. The bands represent DNA fragments and serve for genotype identification, similarity comparison among analysed genotypes, or for the link analysis among some useful properties. The occurrence, number and arrangement of bands are stable for one genotype and as a rule do not depend on ecological factors. In case of amplification of the parts of genome of the species of genus Arum RAPD, the solution was modified according to Guadagnuolo et al. (2001) and consisted in the volume of $25 \mu 1$.

\section{Polymerase chain reaction}

The method of polymerase chain reaction enables the multiple DNA in vitro. For this treatment one molecule of DNA is sufficient and it needs to be multiple (so-called template molecule of DNA), one molecule of monomial DNA (so-called primer) which will set the boundaries of the template place, four molecules of deoxyribonucleotide phosphates, enzyme polymerase and a source of warmth. The number of new DNA, which needs to be synthesised, is increased exponentially to $2 \mathrm{n}$ during several hours (Fig. 1). One DNA molecule produced about 1048576 new DNA molecules during 20 cycles. The whole process was performed in about 40 cycles and the result of this multiple DNA is finally $10^{9}$ molecules (Delić 1997). For multiple DNA fragments of the species of genus Arum Biometra T gradient and T3 Termocycler (Whatman Biometra, Göttingen) were used with the following treatment: denaturation during 5 minutes at $94^{\circ} \mathrm{C}, 40$ cycles in a minute at $93^{\circ} \mathrm{C}$, the link of DNA primer and the link of DNA template during one minute at $40^{\circ} \mathrm{C}$ to $44^{\circ} \mathrm{C}$ and the DNA chain length during one minute at $72^{\circ} \mathrm{C}$.

\section{Electrophoresis}

This is the method for separating macromolecules either of DNA, of RNA or proteins of different electrical charge in an agar gel in electrical field through the opposite electrical charge from itself, as well as their isolation, cleanse and characterisation (Delić 1997). Nucleic acids are slightly negative and therefore they are attached to the positive electrode. The dimension of DNA segments in comparison with the known marks gives the electrophoresis. Bands of DNA fragments with this gel product could be seen by ad-

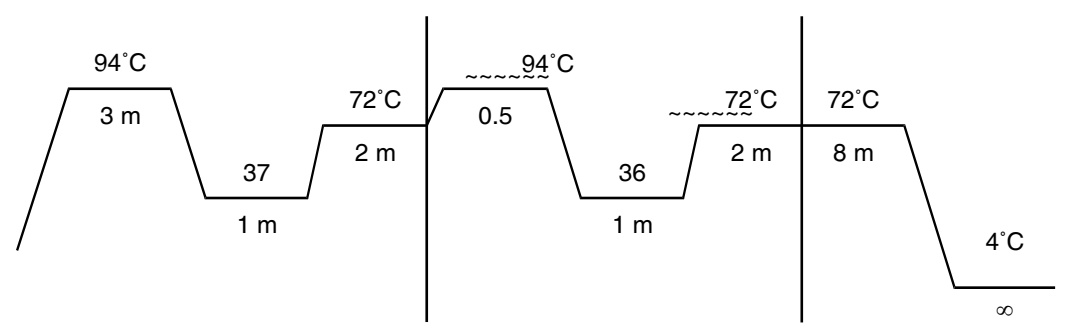

Fig. 1. Thermal Cycler condition for RAPD-PCR reaction. 


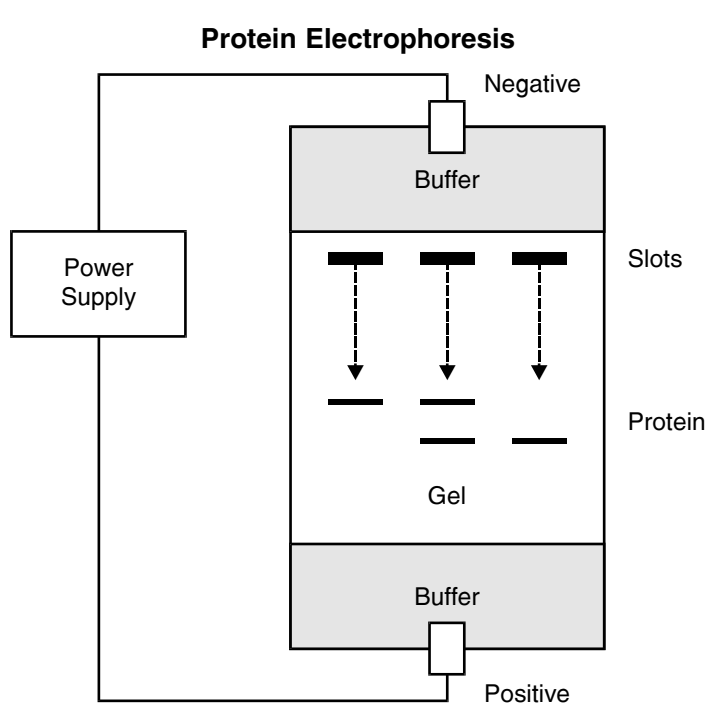

Fig. 2. Scheme of the gel electrophoresis

ding an intercalary colour ethidium bromide, which in UV light is fluorescent. Multiple products of DNA fragments of the species of genus Arum were separated in $1.6 \%(\mathrm{w} / \mathrm{v})$ agar gel in $0.5 \%$ TBE (tries borate) at $100 \mathrm{~V}$, coloured by fluorescence ethidium bromide and photographed at UV light with the gel documentation system (BioRad Hercules, Ca, USA) (Fig. 2).

\section{Statistical analysis of obtained data by RAPD method}

The treatment of the obtained data by the RAPD method begins by record making of the electropherogram with molecular analysis software version 1.5 (BioRad, Hercules, CA, USA). For each version number 1 was recorded, when the band individuals existed, or 0 if the band did not exist. The band presence/absence was recorded in the Excel table. The matrix of genetic resemblance was accounted from the binary table according to Jaccard asymmetrical coefficient (Jaccard 1980): $\mathrm{Sj}=\mathrm{a} /(\mathrm{a}+\mathrm{b}+\mathrm{c})(\mathrm{a}-$ number of fragments shared by both individuals, $\mathrm{b}$ and $\mathrm{c}$ - number of fragments characteristic for certain individuals).

For statistical meaning of the species and population, as well as for the separation, the Mantel test was used (Mantel 1967) within R4 parcel (Phillipe Casgrain \& Pierre Legendre, Universities de Montreal).

The similarity matrix was converted to the distance of matrix according to the formula: $D_{1}=1-S_{i}$ and compared with the matrix in which the two individuals of the same species had values 1 , whereas the two individuals of different species or population had values 0 . The obtained $r-$ values were interpreted as a correlation coefficient. The distance matrix as principal coordinates analysis ( $\mathrm{PCoA})$ was used (Gower 1996).

\section{RESULTS AND DISCUSSION}

\section{Karyological investigations}

Studies of chromosomes pointed out that number of chromosomes for each of the individuals within the species Arum italicum Mill. accounted $2 \mathrm{n}=84$, in Arum maculatum L. $2 \mathrm{n}=56$, and in Arum alpinum Schott \& Kotschy $2 \mathrm{n}=28$.
Between the two varieties of Arum maculatum L., var. maculatum L. and var. immaculatum Reichb., as well as between varieties of Arum alpinum Schott \& Kotschy var. pannonicum Terpó and var. intermedium Terpó, no differences in the number of chromosomes were found. On the basis of these parameters no hybrids were found either. But such finding does not mean that hybrids exist at these localities. They are probably present in this region, but have not been detected so far. (Bedalov et al. 1994). Therefore future studies should be dedicated to this problem. It should be also stressed that these investigations of chromosomes did not only completely coincide with, but were also supported by the studies of Bedalov (1975-1977, 1981, 1983) and Bedalov et al. (1998).

\section{Results obtained by RAPD method}

By this method 46 individuals were studied and they belonged to three species and represented 11 populations from the 4 localities. For their studies 5 monomials were used as follows (Table 1). Under the assumption that every band with different molecular weight represents a unique locus, as well as fragments amplified with different primers (Schoenenberger 2001), these 5 monomials gave either 70 locus or in average of 14 , according to the primers. However, this number varies from 8 to 17 fragments according to the primers (Fig. 3). Since the RAPD markers are dominant, it is supposed that each band represents the phenotype at the simple biallelic locus (Williams at al. 1990).

TABLE 1. Primers DNA used in RAPD method.

\begin{tabular}{ll}
\hline Primers & Sequence $\left(5^{\prime}-3^{\prime}\right)$ \\
\hline OPB 15 & GGAGGGTGTT \\
OPB 20 & GGACCCTTAC \\
OPT 6 & CAAGGGCAGA \\
OPT 7 & GGCAGGCTGT \\
OPT 18 & GATGCCAGAC \\
\hline
\end{tabular}

The Jaccard's coefficients (Jaccard 1980) of similarities were used to make the dendrogram with arithmetic mean algorithm (Sokal and Rohlf 1981). For this the program of Cluster Package Software (Brzustowski 1999) Unweighted Pair Group Method with Arithmetic Mean (UPGMA) was used. The dendrogram was visualised by the use of the program Treeveiw Package Softwere (Page 1998) (Fig. 4). In the dendrogram 46 individuals were separated; 10 individuals belonged to the species Arum italicum Mill. (Zablaće: $\mathrm{Z}_{11}-\mathrm{Z}_{15}$ and Normanci: $\mathrm{N}_{11}-\mathrm{N}_{15}$ ); 10 individuals belonged to the species Arum maculatum L. var. maculatum L. (Normanci: $\mathrm{N}_{6}-\mathrm{N}_{10}$ and Zablace: $\left.\mathrm{Z}_{6}-\mathrm{Z}_{10}\right) ; 10$ individuals belonged to the species Arum maculatum L. var. immaculatum Reicbh. (Normanci: $\mathrm{N}_{1}-\mathrm{N}_{5}$ and Zablace: $\mathrm{Z}_{1}-\mathrm{Z}_{5}$ ) and 16 individuals belonged to the species Arum alpinum (Bilje: $\mathrm{B}_{1^{-}}$ $-\mathrm{B}_{10}$ and Branjin $\mathrm{Vrh}: \mathrm{BV}_{1}-\mathrm{BV}_{5}$ ). Three species were particularly visibly separated. These were: Arum italicum $\left(\mathrm{Z}_{11}\right.$ $-\mathrm{N}_{15}$ ); Arum maculatum $\left(\mathrm{N}_{5}-\mathrm{N}_{6}\right)$ and Arum alpinum (V$\left.-\mathrm{BV}_{3}\right)$. Inside the group of Arum maculatum $\left(\mathrm{N}_{5}-\mathrm{N}_{6}\right)$ it was possible to differ two groups: $\mathrm{N}_{6}-\mathrm{N}_{9}$ in which was Arum maculatum L. var. maculatum $\mathrm{L}$. and $\mathrm{N}_{2}-\mathrm{N}_{5}$ in which was Arum maculatum L. var. immaculatum Reicbh.)

In analysing principal coordinates (PCoA) the matrix of distance was used (Gower 1966). This (PCoA) scatter plots 


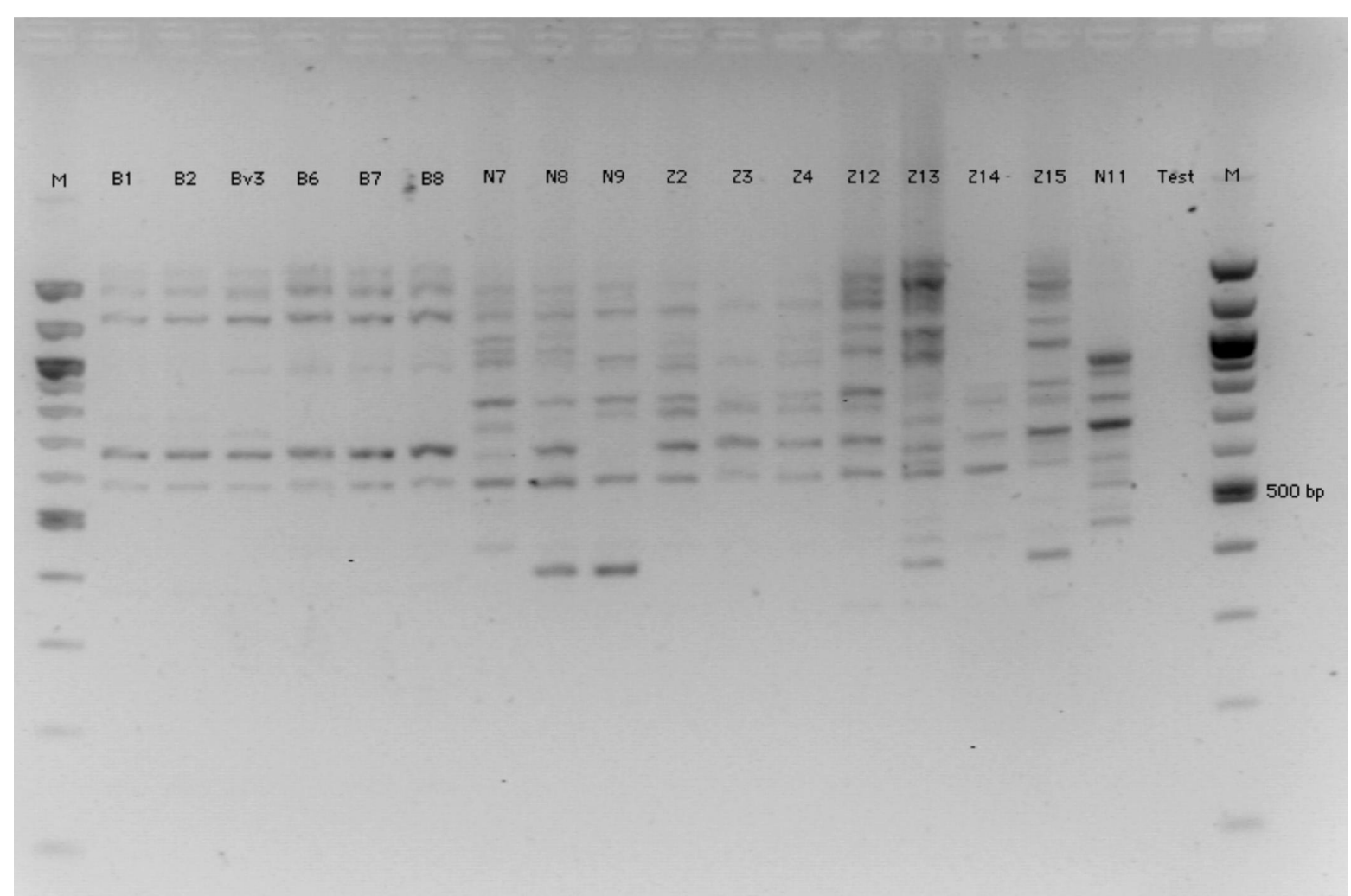

Fig. 3. Example of RAPD amplification: electropherogram obtained by using primer OPT 7.

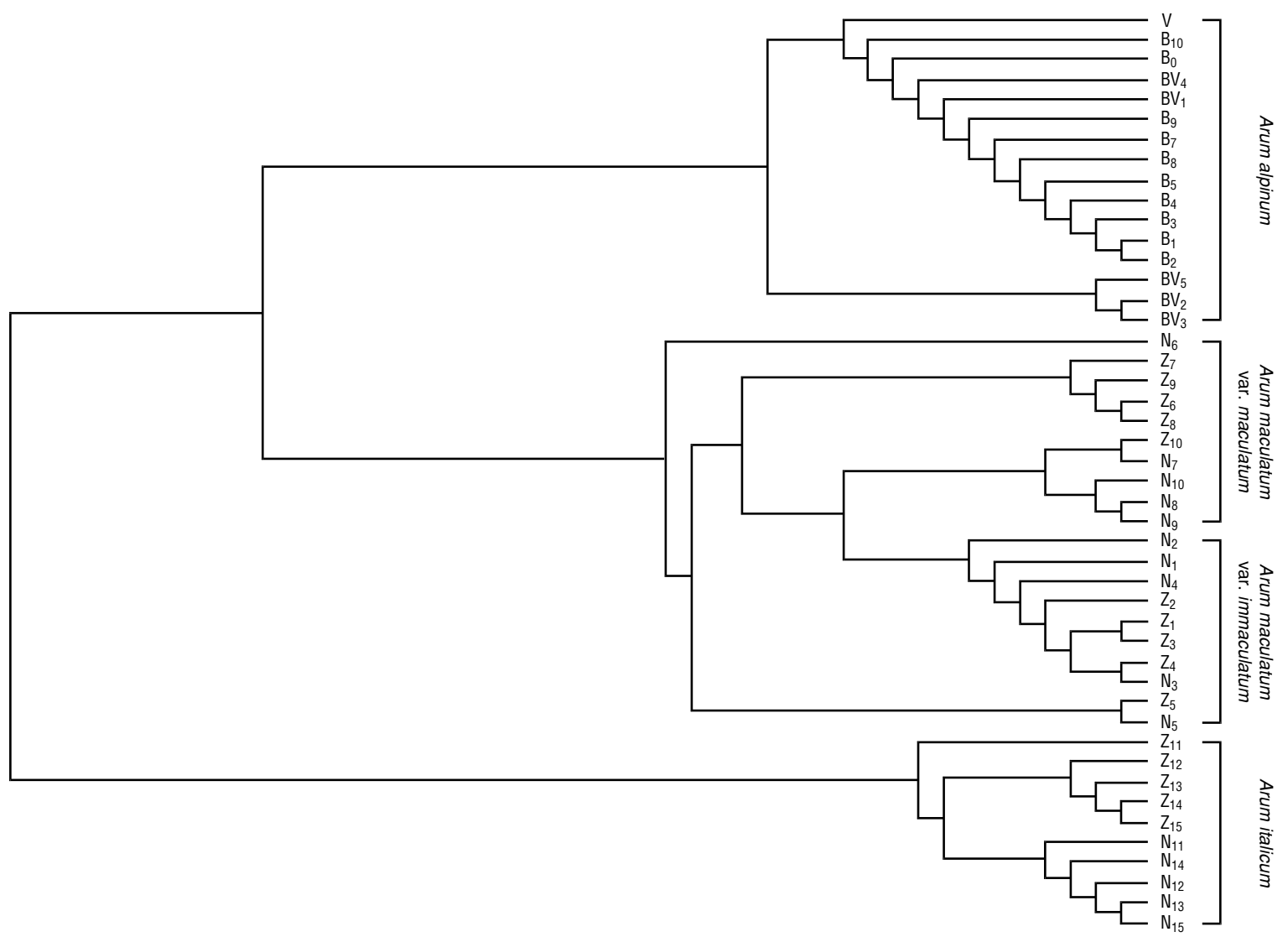

Fig. 4. UPGMA Dendrogram of species of genus Arum in Slavonia and Baranya region in Croatia obtained on the principle of amplification with five primers. 


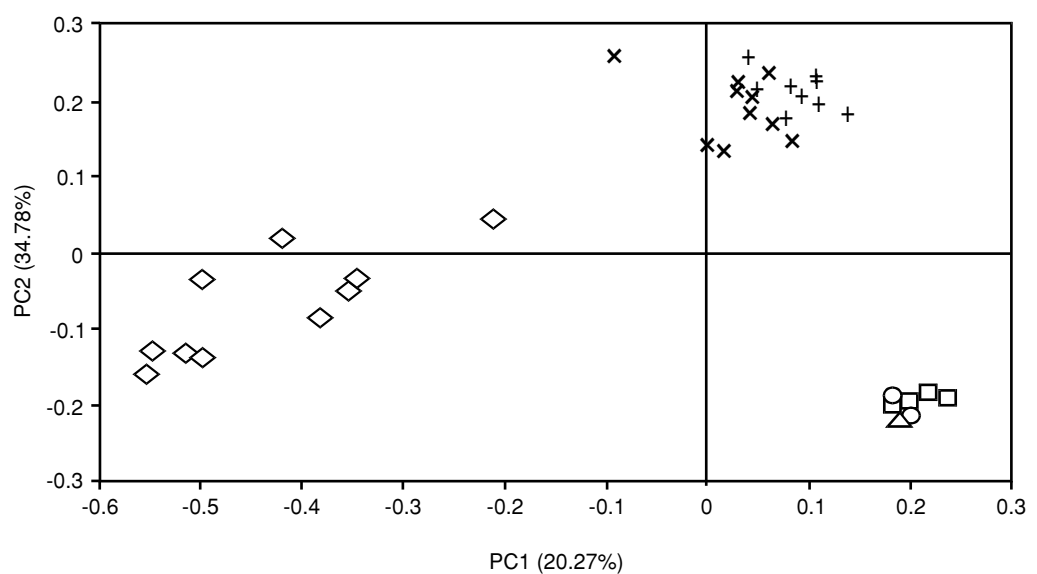

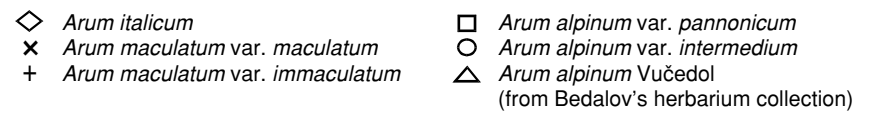

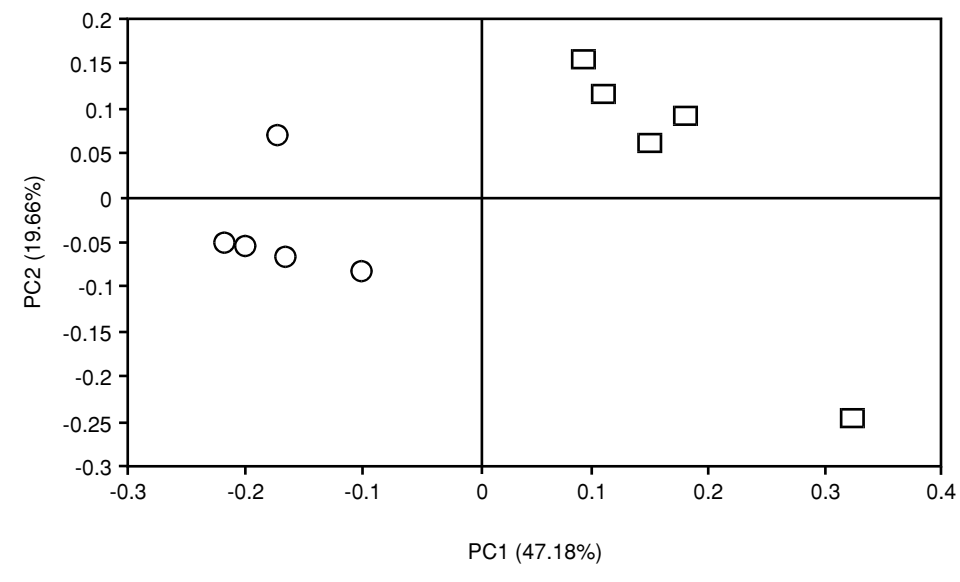

Arum italicum Mill. Normanci
Fig. 5. PCoA of species of genus Arum found in Slavonia and Baranya region in Croatia. gave the following pieces of information that are clearly evident.

The existence of separation of the species of genus Arum in Eastern Slavonia region in Croatia as the obtained results by RAPD methods showed (Fig. 5).

The detected individual variability inside populations and the variability between populations of the species Arum italicum Mill. in the habitats of Normanci and Zablace in the Eastern Slavonia region were found (Fig. 6).

The detected individual variability inside populations and the variability between populations of the species Arum maculatum L. var. maculatum L. in the habitats of Normanci and Zablaće in Eastern Slavonia region were determined (Fig. 7).

The detected individual variability inside populations and between populations of the species Arum maculatum L. var. immaculatum Reicbh. in the habitats of Normanci and Zablaće in Eastern Slavonia region were shown (Fig. 8).

The detected individual variability inside populations and between populations of the species Arum alpinum Schott \& Kotschy var. pannonicum in the habitats of Bilje and Branjin Vrh in Baranya region were found (Fig. 9).
The variability among varieties of the species Arum in the Baranya region in Croatia as the obtained results by RAPD method show:

The detected variability between varieties of the species Arum alpinum Schott \& Kotschy var. pannonicum Terpó and Arum alpinum Schott \& Kotschy var. intermedium Terpó in the habitats of Bilje (Fig. 9).

It could be noted that there was also the variability between varieties of the species Arum italicum Mill., Arum maculatum L. var. maculatum L., Arum maculatum L. var. immaculatum Reicbh. and Arum alpinum Schott \& Kotschy var. pannonicum Terpó and var. intermedium Terpó in the habitats in Eastern Slavonia and Baranya region (Fig. 10). The species Arum italicum Mill. varied the most and the species Arum alpinum Schott \& Kotschy varied the least. By condensing the results obtained it is possible to differ two genetically separated groups corresponding to the species Arum italicum Mill., Arum maculatum L and Arum alpinum Schott \& Kotschy.

The group of individuals of the species Arum italicum Mill. is the least homogenous and its individuals are mutually related. However, they are very closely separated and 


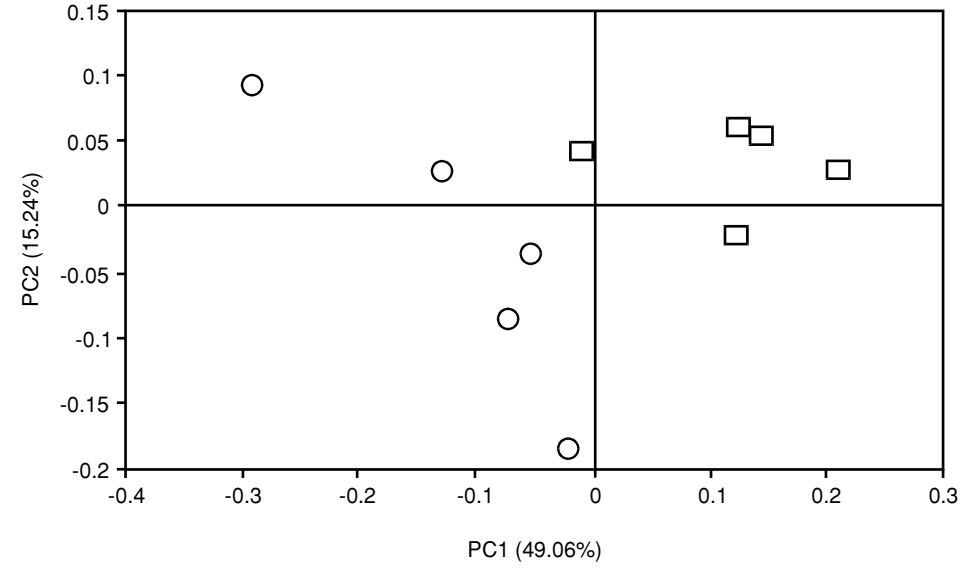

Arum maculatum L. var. maculatum Normanci $\square$ Arum maculatum L. var. maculatum Zablaće

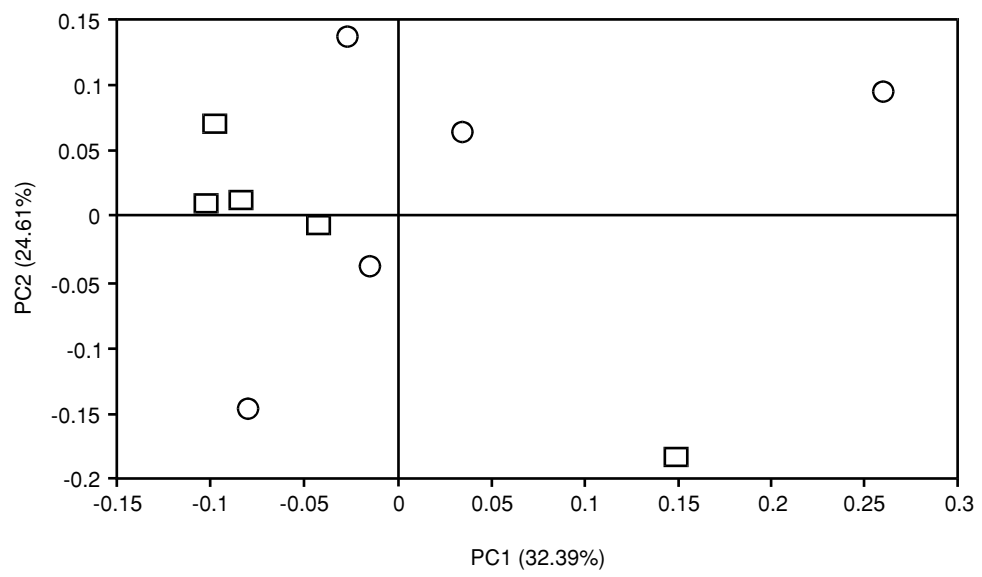

$\bigcirc$ Arum maculatum L. var. immaculatum Normanci $\square$ Arum maculatum L. var. immaculatum Zablaće

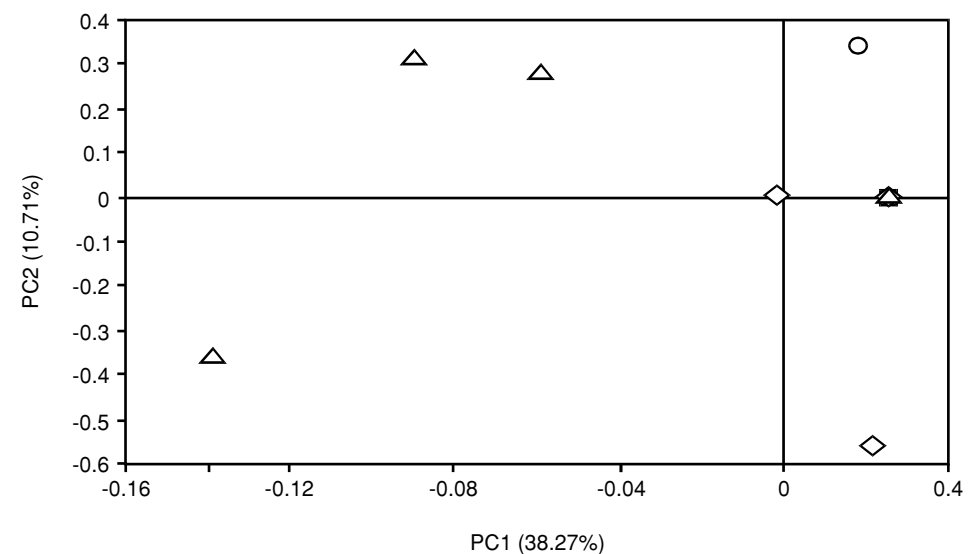

Arum alpinum Vučedol (from Bedalov's herbarium collection)

$\square$ Arum alpinum var. pannonicum Bilje

$\triangle$ Arum alpinum var. pannonicum Branjin vrh

Arum alpinum var. intermedium Bilje
Fig. 7. PCoA. Variability between populations of species Arum maculatum L. var. maculatum $\mathrm{L}$.
Fig. 8. PCoA. Variability between populations of species Arum maculatum L. var. immaculatum Reichb. do not show relationships with the other species group of genus Arum. These species are more distinguished in relation to the other two groups. It should be also noticed that the variability of this species between populations is very high because they are mutually separated, but are still close to each other.
Fig. 9. PCoA. Variability of the species Arum alpinum Schott. \& Kotschy var. pannonicum Terpó and. var. intermedium Terpó. 

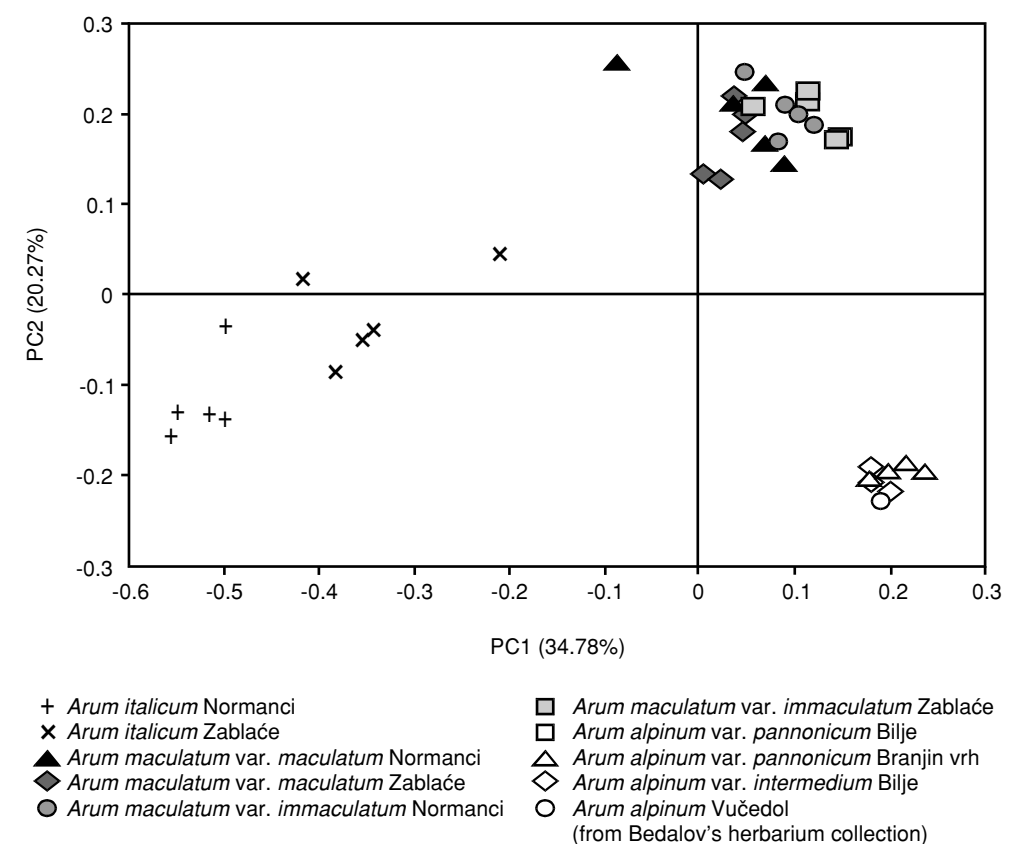

$\square$ Arum maculatum var. immaculatum Zablaće
$\square$ Arum alpinum var. pannonicum Bilje
$\triangle$ Arum alpinum var. pannonicum Branjin vrh
$\diamond$ Arum alpinum var. intermedium Bilje
$\mathrm{O}$ Arum alpinum Vučedol
(from Bedalov's herbarium collection)

Fig. 10. PCoA. Variability of the species Arum in Eastern Slavonia and Baranya region in Croatia.
The group of individuals of the species Arum maculatum L. is more homogenous and within it could be differed the two more or less separated groups corresponding to the two varieties, var. maculatum L. and var. immaculatum Reicbh. Therefore, they are genetically related, but not maximally since it is possible to differ the two varieties. Moreover, they do not show any relationship with the other species of genus Arum. It should be also remarked, that the variability between populations is high, particularly between populations of var. immaculatum, as it is difficult to differ two mutually separated groups of populations.

The group of individuals of the species Arum alpinum Schott \& Kotschy is very homogenous and it is extremely difficult to differ the two varieties of the species, var. pannonicum Terpó and var. intermedium Terpó, so it could be said that they are very closely related and as result of this they closely resemble. Also, they do not show any relationship with the other species of genus Arum. In addition the variability between populations of the species Arum alpinum is too high, but only in the habitat of Bilje, since the population var. pannonicum is very homogenous, the individuals of varieties intermedium, however are less homogeneous. Individuals of populations var. pannonicum in the habitat Branjin Vrh are either more or less scattered. It is necessary to note that it is also extremely difficult to differ the one from the other varieties.

Finally, it is visible from figure 10 that the species Arum italicum Mill., Arum maculatum L. and Arum alpinum Schott \& Kotschy are separated and clean and they are mutually minimally related. Observations by RAPD method indicate that there were found no data for the differentiation between two varieties of Arum alpinum Schott \& Kotschy, var. pannonicum Terpó and var. intermedium Terpó, although the morphological studies show clear differences between them. In contrast to two varieties of the species Arum maculatum L., var. maculatum L. and var. immaculatum Reicbh., between which data for their differentiations obviously exist, which is in concordance with the morphological parameters (Lendel et al. 2004). Moreover, it has also been noted in general that the variability of individuals existed either inside the same population or between different populations.

The new assumption (Lendel et. al. 2004) suggested that the species Arum alpinum Schott \& Kotschy, with two varieties, var. pannonicum and var. intermedium Terpó, is actually Arum cylindraceum. The studies made by the RAPD method showed that Arum cylindraceum can clearly be distinguished from both Arum italicum Mill. and Arum maculatum L.

\section{ACKNOWLEGMENT}

Anita Lendel is grateful to the Institute of Botany in Neuchâtel in Switzerland, particularly to Professor P. Küpfer, for research facilities in the Plant Morphology section as well as to Professor M. Bedalov and Dr. Schoenenberger for cooperation.

\section{LITERATURE CITED}

BEDALOV M. 1975. Cytotaxonomical and phytogeographical investigations of the species Arum italicum Mill. in Yugoslavia. Acta Bot. Croat. 34: 143-150.

BEDALOV M. 1976. Citotaksonomska i biljnogeografska istraživanja vrste Arum alpinum Schott i Kotschy u Jugoslaviji. Glasnik Prirodnjačkog muzeja, Serija B, Knjiga 31. (in Croatian)

BEDALOV M. 1977. Citotaksonomska i biljnogeografska istraživanja vrste Arum maculatum L. u Jugoslaviji. Acta Bot. Croat. 36: 107-117. (in Croatian)

BEDALOV M. 1981. Cytotaxonomy of the genus Arum (Araceae) in the Balkans and the Aegean area. Bot. Jahrb. Syst. 102: 183-200.

BEDALOV M. 1983. Distribution of the species Arum alpinum Schott \& Kotschy in West Mediterranean area. Rapp. Comm. Int. Medit.28: 107-109. 
BEDALOV M., FISCHER M. 1994. Arum alpinum (Araceae) and its distribution in Eastern Mediterranean. Phyton 35 (1): 103-113 .

BEDALOV M., FAVAGER C., KÜPFER F. 1998. Natural hybrids and chromosome number in the genus Arum. Acte Bot. Yunn. Supl.: 71-75.

BOYS P. 1993. The genus Arum. A Kew Magazine Monograph. The Royal Botanic gardens, Kew.

BRZUSTOVSKI K. 1999. Cluster package. Alberta, Ca

DELIĆ V. 1997. Genetičko inženjerstvo u biotehnologiji (osnovne manipulacije genima). Manualia Univesitatis Studiorum Zagrebiensis, MCMXCVII. (in Croatian)

DOMAC R. 1994. Flora Hrvatske. Priručnik za odreðivanje bilja. Školska knjiga, Zagreb. (in Croatian)

FLORA EUORAPEA 1964-1980. Alismataceae to Orchidaceae. T.G. Tutin, V.H. Heywood, N.A. Burges, D.M. Moore, D.H Valentine, S.M. Walters, D.A. Weeb (eds). Cambridge University Press, Cambridge-Sydney.

GOWER J.C. 1966. Some distance properties of latenrootand vector methods used in multivariate analysis. Biometrica 53: 325-338.

GUADAGNUOLO R., SAVOVA-BIANCHI D., FELBER F. 2001. Specific genetic markers for wheat spelt and four wild relatives: comparison of isoenzymes, RAPDs and wheat micro satellites. Genome 44: 610-621.

JACCARD P. 1980. Novellas researches sur la distribution floral. Bull. Soc. Vaud. Sci. Nat. 44: 223-270.

LENDEL A., SCHOENENBERGER N., BEDALOV M., YONGMING Y., KÜPFER P. 2004. Molecular, morphological and karyological studies of some Arum species in Euorpe. [Poster at the Biology 04, Fribourg, Switzerland]

MANTEL N. 1967. The detection of the disease clustering and a generalized regression approach. Cancer research 27: 209-220.

PRIME C.T. 1961. Taxonomy and nomenclature in some species of the genus Arum L. Watsonia: 5 (2): 106-109.

REINCHENBACH H.G.L. 1830. Araceae. In: Flora Germania Excursoria 138, Leipzig.

SCHONENBERGER N. 2001. RAPD-based genetic diversity of Arum cyliandraceum, Arum maculatum and Arum italicum in Italy. Diploma work in natural science. Univesity of Neuchâtel.

SCHOTT H.W. 1860. Gymnomesium \& Arum. In: Prodromus Systematis Aroidearum. 73-102, Vienna.

SCHOTT H.W., KOTCSHY T. 1851. Ein neues Arum. Botanische Zeitung, Berlin. 9: 285.

SOKAL R.R., ROHLF F.J. 1981. Biometry. W.H. Freeman, New York.

TERPÓ A. 1971. Arum - rendszertani kutatasok Magyerorszagom. Bot. Këzlem 58: 150-160. (in Hungarian)

TERPÓ A. 1973. Kritishe Revision der Arum - Arten de Karpaten. Acta Bot. Acad. Sci. Hung. 18: 81-85.

TERPÓ A. 1992. Distribution and taxonomy of Arum species in Pannonian territories. Aroid conference, Moscow, Aroideana 15: 24-30.

WILLIAMS J., KUBELIK A.R., LIVAK K.J., RAFALSKI J.A., TINGEY S.V. 1990. DNA polymorphisms amplified by arbitrary primers are useful as genetic markers. Nucleic acid research 18: 6531-6535. 